\title{
REZULTATI PILOT-ISTRAŽIVANJA O POTREBAMA I OČEKIVANJIMA KNJIŽNIČARA OD DRUŠTVA KNJIŽNIČARA BILOGORE, PODRAVINE I KALNIČKOG PRIGORJA
}

\author{
RESULTS OF THE PILOT RESEARCH ABOUT \\ THE NEEDS AND EXPECTATIONS OF THE LIBRARIANS \\ FROM THE ASSOCIATION OF LIBRARIANS \\ OF BILOGORA, PODRAVINAAND KALNIK COUNTIES
}

\begin{abstract}
Romana Horvat
Pučka knjižnica i čitaonica Daruvar

pkic@bj.t-com.hr

\section{Lucija Miškić}

Narodna knjižnica „Petar Preradovićc“ Bjelovar lucija.miskic@gmail.com

\section{Ljiljana Vugrinec}

Knjižnica i čitaonica „Fran Galović“ Koprivnica

ljiljana@knjiznica-koprivnica.hr
\end{abstract}

UDK / UDC 061.2:023.5(497.5)

Istraživanje / Research

Prihvaćeno / Accepted: 16. 5. 2017.

\section{Sažetak}

Rad donosi pregled i analizu rezultata pilot-istraživanja Društva knjižničara Bilogore, Podravine i Kalničkog prigorja o potrebama i očekivanjima knjižničara od ovoga društva - regionalne udruge knjižničara koja ima četrdesetogodišnju tradiciju (osnovana je 1977. godine) te djeluje na području tri županije: Bjelovarsko-bilogorske, Koprivničko-križevačke i Virovitičko-podravske. Društvo trenutno okuplja 115 članova iz 66 školskih, narodnih i specijalnih knjižnica, a u anketnom ispitivanju sudjelovalo

Vjesnik bibliotekara Hrvatske 60, 1(2017), 221-242

ISSN 0507-1925

(C) VBH 2017. 
je 77 knjižničara s područja djelovanja Društva neovisno o statusu članstva. Ciljevi pilot-istraživanja bili su saznati potrebe i očekivanja članova i nečlanova od Društva, približiti aktivnosti Društva njihovim interesima i potrebama te potaknuti knjižničare na učlanjivanje u Društvo. Istraživanjem su detektirana problematična područja u radu ovog regionalnog društva knjižničara te su dobivene smjernice za učinkovitije i produktivnije djelovanje.

Ključne riječi: Društvo knjižničara Bilogore, Podravine i Kalničkog prigorja, regionalno udruženje knjižničara, pilot-istraživanje, interesi i potrebe knjižničara

\section{Summary}

The paper provides an overview and analysis of the results of the pilot research conducted by the Association of Librarians of Bilogora, Podravina, and Kalnik Counties among the librarians investigating the needs and expectations they have from their regional library association. The Association of Librarians of Bilogora, Podravina, and Kalnik Counties is a regional association of librarians with a forty years old tradition (established in 1977), and it is covering three counties: Bjelovar-Bilogora, Koprivnica-Križevci and Virovitica-Podravina. Today the Association has 115 members from 66 school, public, and specialized libraries. Seventy-seven librarians from the targeted areas have participated in this pilot research, regardless of their membership status (both members and non-members). The main goals of the pilot research were to find out the needs and expectations the members as well as non-members have from the Association, to bring closer the Association's activities to the interests and needs of the members, and to promote the Association and encourage the librarians to become members of the Association. The survey detected the main problems and provided useful guidelines on how the Association can be more efficient and productive in the future.

Keywords: Association of Librarians of Bilogora, Podravina, and Kalnik Counties, Regional Association of Librarians, pilot research, interests and needs of librarians

\section{Uvod}

Društvo knjižničara Bilogore, Podravine i Kalničkog prigorja u sastavu je matične udruge - Hrvatskog knjižničarskog društva, s kojim je udruženo još 15 regionalnih knjižničarskih društava s područja cijele Hrvatske. To znači da su članovi bilo kojeg regionalnog društva ujedno i članovi Hrvatskog knjižničarskog društva. Ovim pilot-istraživanjem dobivene su vrlo bitne povratne informacije o interesima i potrebama knjižničara, članova i nečlanova, od regionalnog Društva knjižničara Bilogore, Podravine i Kalničkog prigorja i Hrvatskog knjižničarskog društva. Rezultati ovog pilot-istraživanja mogu pružiti uvid u probleme s kojima 
se susreće regionalno udruženje knjižničara, ali i interese i potrebe knjižničara od regionalnog udruženja.

Društvo knjižničara Bilogore, Podravine i Kalničkog prigorja (dalje u tekstu: Društvo) djeluje četrdeset godina s ciljem okupljanja knjižničnih djelatnika iz svih vrsta knjižnica i poticanja njihova stručnog usavršavanja. Društvo je osnovano 1977. godine i tada je brojalo 30 članova. Ciljevi Društva propisani su Statutom:

- unapređivanje knjižničarske struke i knjižnične djelatnosti općenito

- poticanje stručnog i znanstvenog rada knjižničnih djelatnika te davanje javnih priznanja zaslužnim članovima

- zalaganje za odgovarajući društveni i ekonomski položaj djelatnika s knjižničarskim zvanjima

- poticanje osnivanja, razvitka i suradnje svih vrsta knjižnica i širenje zanimanja društva za knjigu i knjižnicu

- poticanje prikupljanja i zaštite zavičajne baštine

- sudjelovanje u kreiranju i provedbi politike na području knjižničarstva

- surađivanje s drugim knjižničarskim društvima.

Društvo provodi razne aktivnosti kojima pridonosi ostvarivanju navedenih ciljeva. Tako primjerice svake godine Društvo organizira godišnju skupštinu koja se sastoji od stručnog islužbenog dijela. Stručni dio sastoji se od izlaganja članovaigostiju na određenu aktualnu temu iz područja knjižničarstva, a u službenom dijelu donose se prema potrebi izmjene podzakonskih akata, prihvaćaju se planovi i izvješća te se imenuju članovi u pojedina tijela Društva, kao i u komisije i radne grupe Hrvatskog knjižničarskogdruštva. Pored toga, Društvoizdaje popularno-stručni časopis Svezak koji je prvi put pokrenut 1985. godine, a od 1999. godine do danas redovito izlazi kao godišnjak. Povremeno za članove Društvo organizira i stručne izlete.

Članovi Društva od samih su početaka vrlo aktivni, a njihov broj bio je u kontinuiranom porastu sve do 2009. godine. Broj članova bilježi se u interni Adresar članova Društva te je kontinuirani porast članstva vidljiv i u spomenutom dokumentu. Društvo je 2009. godine brojalo 140 članova. Detaljan proces revidiranja članstva završen je 2015. zbog usklađivanja poslovanja Društva s novim Zakonom o udrugama te je utvrđeno da Društvo broji 115 članova, što znači da je u razdoblju od 2009. do 2015. zabilježen pad članstva za 18\% (25 članova manje). Samim time razumljivo je da se tijekom godina postupno sve više smanjivao i broj knjižničara koji dolaze na godišnje skupštine.

Vođen tim osjetnim padom broja članova, Glavni odbor Društva donio je odluku da će 2015. godine provesti istraživanje i osmisliti anketni upitnik kojemu je cilj omogućiti uvid u potrebe i očekivanja knjižničara, članova i nečlanova, od Društva, približiti aktivnosti Društva interesima i potrebama članova te potaknuti knjižničare na učlanjivanje u Društvo. 


\section{Metoda provedbe istraživanja}

Istraživanja su sastavni dio upravljanja udruženjima (društvima) te su važna za strategijski razvoj udruženja. Bez istraživanja mišljenja članova i nečlanova društava knjižničara, koji su središnja točka postojanja društva, nemoguće je saznati dodatne detalje koji potom postaju parametri u planiranju rada društva knjižničara $u$ različitim razdobljima.

Upravo u svrhu istraživanja mišljenja članova i nečlanova Društva te traženja razloga vidljivog pada broja članova Društva osmišljeno je pilot-istraživanje informativnog karaktera kojim će se predvidjeti odgovarajuće veličine uzorka (uzorak nije kontroliran i reprezentativan) i poboljšanja prije početka istraživačkog projekta širih razmjera.

Pilot-istraživanje provedeno je metodom anketiranja, a kao sredstvo anketiranja poslužio je online anketni upitnik napravljen pomoću Googleova obrasca (prilog 1). Pitanja, njih 27 (zatvorenog tipa 16, a otvorenog tipa 11), u upitniku su razvrstana prema sljedećim skupinama:

- podaci o ispitaniku

- članstvo u Društvu, članarina i informiranje o radu Društva

- aktivnost i sudjelovanje u radu Društva

- područja interesa ispitanika

- ciljevi učlanjivanja i očekivanja od Društva.

Anketa je bila dostupna za popunjavanje od 14. ožujka do 15. travnja 2016., ukupno 48 dana. Anketno istraživanje bilo je namijenjeno svim knjižničarima zaposlenima u knjižnicama na području djelovanja Društva neovisno o tome jesu li ili nisu članovi Društva. Poziv za ispunjavanje anketnog upitnika poslan je u dva navrata na 160 adresa e-pošte knjižničara s područja djelovanja Društva. Kako bi upitnik došao do svih knjižničara, poziv za ispunjavanje ankete proslijedili su voditelji županijskih matičnih službi i voditelji županijskih stručnih vijeća za školske knjižnice Bjelovarsko-bilogorske, Koprivničko-križevačke i Virovitičko-podravske županije svim knjižnicama u svojim županijama.

To je rezultiralo time da je anketu popunilo 77 knjižničara. Od toga, $79 \%$ ispitanika (njih 61) članovi su Društva ili 67\% ukupnog članstva (s obzirom na to da Društvo broji 115 članova), a 21\% ispitanika (njih 16) nije učlanjeno (od toga $16 \%$ ispitanika (njih 12) nikad nisu bili članovi, a 5\% ispitanika (njih 4) bivši su članovi Društva). 


\section{Rezultati istraživanja}

\subsection{Profil ispitanika}

Prva grupa pitanja imala je za cilj prikupiti opće informacije o dobi, spolu, radnom stažu u knjižničarstvu, stručnoj spremi / znanstvenom stupnju, zvanju u knjižničarstvu i radnom statusu. Tim pitanjima dobiven je uvid u profil ispitanika.

Pokazalo se da je najveći broj ispitanika u tridesetim 57\% (njih 44) i četrdesetim 25\% (njih 19) godinama. Po brojnosti slijede ispitanici u pedesetim godinama života - 8\% (njih 6), a najmanje je starijih od šezdeset - 5\% (njih 4) ili mlađih od trideset godina - 5\% (njih 4). Većina ispitanika diplomirani su knjižničari - 74\% (njih 57), a zatim slijede pomoćni knjižničari - 10\% (njih 8). Knjižničara je 5\% (njih 4), viših knjižničara i knjižničara savjetnika 5\% (njih 4), stručnih suradnika knjižničara mentora $4 \%$ (njih 3), a stručnih suradnika - knjižničara savjetnika $1 \%$ (1 ispitanik). Što se tiče ustanova u kojima ispitanici rade, prevladavaju zaposleni u školskim knjižnicama - 49\% (njih 38) i narodnim knjižnicama - 46\% (njih 35), a svega $5 \%$ (njih 4) pripada ostalim vrstama knjižnica. Većina ispitanika ima radni staž od 5 do 10 godina $-40 \%$ (njih 31), zatim slijede zaposlenici sa stažem od 10 do 20 godina $-28 \%$ (njih 22 ), $16 \%$ (njih 12) sa stažem do 5 te $16 \%$ (njih 12) s više od 20 godina radnog staža.

\section{2. Članstvo u Društvu, članarina i informiranje o radu Društva}

Drugom skupinom pitanja obuhvaćene su formalne informacije o članstvu i članarini te o načinu informiranja ispitanika o radu Društva.

U uvodu ovog rada navedeno je kako je 79\% ispitanika (njih 61) učlanjeno u Društvo, a $21 \%$ ispitanika (njih 16) nije učlanjeno (od toga 16\% ispitanika (njih 12) nikad nisu bili članovi, a 5\% ispitanika (njih 4) bivši su članovi Društva). Zanimali su nas razlozi zbog kojih neki od ispitanika nisu učlanjeni u Društvo. U tom anketnom pitanju bilo je moguće odabrati više ponuđenih odgovora. Prema učestalosti odabranih odgovora, rang najčešćih razloga bio je sljedeći: 1 . nedostatak slobodnog vremena za angažiranje i rad u stručnoj udruzi (44\%, 7 ispitanika), 2. nepoznavanje ciljeva i aktivnosti Društva (38\%, 6 ispitanika), 3. nedostatak informacija o mogućnosti učlanjena (25\%, 4 ispitanika), 4. previsoka članarina (19\%, 3 ispitanika) i 5. aktivnosti Društva ne odgovaraju potrebama i očekivanjima ispitanika (13\%, 2 ispitanika). $88 \%$ ispitanika (njih 68) složilo se kako je godišnja članarina u iznosu od 50 kuna odgovarajuća. Navedeni odgovori pokazali su kako u Društvu treba poraditi više na informiranju samih knjižničara o radu, djelatnosti, ciljevima i mogućnostima učlanjenja knjižničara.

U pitanju na koji način prate informacije o radu Društva ispitanici su također mogli odabrati više ponuđenih odgovora. Prema dobivenim odgovorima, obavijesti o radu i aktivnostima Društva ispitanici najčešće prate u časopisu Svezak $(79 \%, 61$ 
ispitanik), zatim kao izvor informacija slijedi mrežna stranica (57\%, 44 ispitanika) te Facebook-stranica Društva (39\%, 30 ispitanika). Od predloženih dodatnih oblika informiranja članova o radu Društva, ispitanici su najviše podržali ideju pokretanja periodičkog newslettera o novostima i aktivnostima u Društvu, slanje kvartalnih e-dopisa članovima, e-mail-obavijesti, otvaranje profila Društva na Twitteru, više radnih dogovora i sastanaka, izdavanje biltena, održavanje predavanja i prezentacija, osmišljavanje brošura, letaka i sl. Časopis Svezak daje vrlo detaljan uvid u rad Društva i rad njegovih članova, ali s obzirom na to da izlazi samo jedanput godišnje, razumljivo je da ponekad postoji potreba za bržim prosljeđivanjem pojedinih informacija. Kako bi se poboljšala komunikacija Društva s članovima, ali i drugim knjižničarima na terenu, jedan od prijedloga iz ankete - izdavanje newslettera Društva - u međuvremenu je već oživotvoren, i prvi broj newslettera objavljen je početkom 2017. godine. Tako se svi knjižničari neovisno o statusu članstva mogu prijaviti na mrežnoj stranici Društva za primanje newslettera.

\subsection{Aktivnost i sudjelovanje članova u radu Društva}

U trećoj skupini pitanja ispitanici su trebali navesti aktivnosti kojima su se bavili ili se bave u Društvu, opisati svoje sudjelovanje u radu Društva, navesti svoja područja interesa te razloge nesudjelovanja u aktivnostima i radu regionalnog Društva i Hrvatskog knjižničarskog društva.

Na pitanje koliko ispitanici sudjeluju na godišnjim skupštinama Društva 35\% ispitanika (njih 27) odgovorilo je da sudjeluje redovito, 27\% ispitanika (njih 21) odgovorilo je da sudjeluje povremeno, dok $21 \%$ ispitanika (njih 16) sudjeluje često. Međutim $17 \%$ ispitanika (njih 13) odgovorilo je kako nikad nisu sudjelovali na godišnjoj skupštini Društva. Anketom se istražilo zašto je tomu tako. Najčešći razlog nesudjelovanja ili samo povremenog dolaska jest preklapanje termina skupštine s drugim obvezama na poslu ispitanika te održavanje skupštine u radnom vremenu (75\%, 12 ispitanika); uprava (ravnatelji) ne omogućava odlazak knjižničara na skupštinu Društva zbog nemogućnosti financiranja i/ili nemogućnosti izostanka s posla (44\%, 7 ispitanika), a treći je po učestalosti odgovor da ispitanici nisu članovi Društva i/ili rade na zamjeni (31\%, 5 ispitanika). Ispitanici su u ovom pitanju imali mogućnost slobodnog upisa odgovora, tako da su odgovori grupirani prema međusobnom podudaranju. Zaključak je da su ispitanici zainteresirani za uključivanje u rad Društva sudjelovanjem u godišnjim skupštinama, ali su u tome spriječeni zbog prethodno navedenih razloga. Kao posebno zabrinjavajući možemo istaknuti manjak podrške ravnatelja knjižnica, iako to predstavlja važan vid stručnog usavršavanja i doprinosi ne samo unapređivanju kompetencija pojedinca već i razvoju struke u cjelini. 


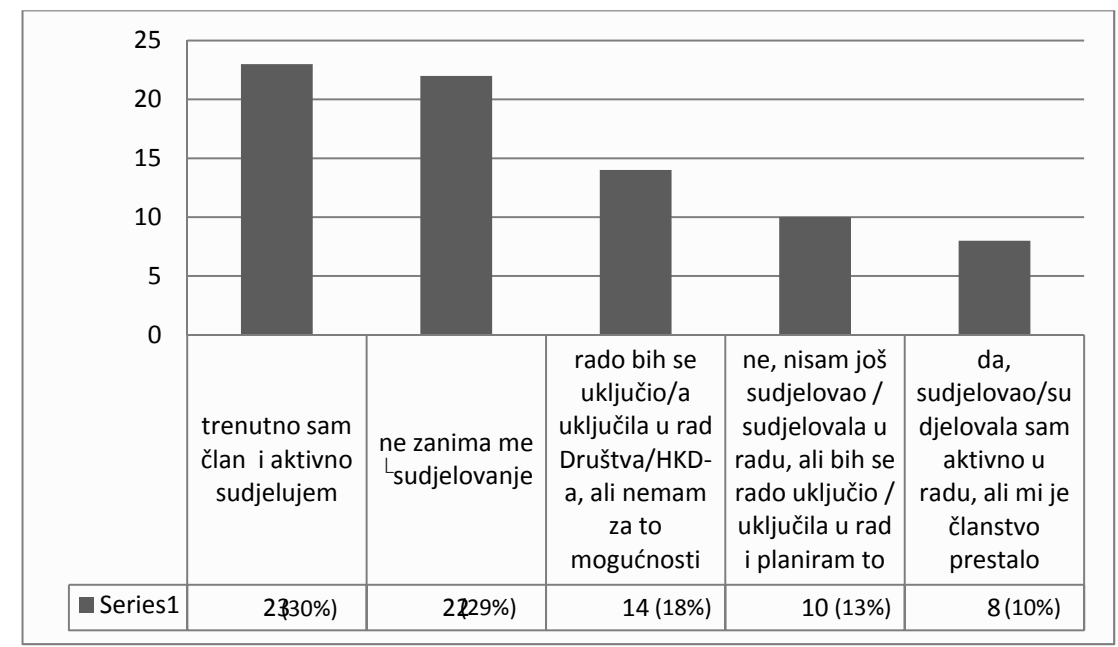

Slika 1. Sudjelovanje u radu stručnih tijela/komisija/sekcija Društva i Hrvatskoga knjižničarskog društva)

Istražilo se i sudjeluju li ispitanici u radu stručnih tijela, komisija i sekcija Društva i Hrvatskog knjižničarskog društva, a odgovori se mogu vidjeti na slici 1. S obzirom na odgovore ispitanika na to pitanje, pojedinim ispitanicima postavljena su potpitanja.

Istražilo se i koja su područja interesa ispitanika. U rad Društva/Hrvatskog knjižničarskog društva planira se uključiti 13\% ispitanika (njih 10). Neka od njihovih područja interesa jesu: rad u Glavnom odboru regionalnog Društva, rad u uredništvu Sveska, bavljenje temama kao što su školske knjižnice, zelene knjižnice, elektroničke knjige, rad s djecom i mladima, zavičajne zbirke i dr.

Od ispitanika koji su odgovorili da nisu još sudjelovali, ali da bi se željeli uključiti u rad Društva/Hrvatskog knjižničarskog društva, no nemaju za to mogućnosti (18\%, 14 ispitanika,) željelo se saznati što ih u tome sprečava. Kod tog pitanja ispitanici su imali mogućnost slobodnog odgovora. Najčešći je razlog nedostatak vremena (43\%, 6 ispitanika), zatim popunjenost mjesta u komisiji/sekciji koja ih zanima, nemogućnost izostanka s posla, stručna sprema i dr.

Na pitanje sudjeluju li i u stručnim izletima u organizaciji Društva, dobiven je odgovor da u zadnjih deset godina 53\% ispitanika (njih 41) nikad nije bilo na takvom stručnom izletu. To je pokazalo kako je u Društvu potrebno preispitati dosadašnje metode organiziranja stručnih putovanja i pokušati organizirati više stručnih izleta, ali na drugačiji način, ovisno o financijama kojima Društvo raspolaže. 


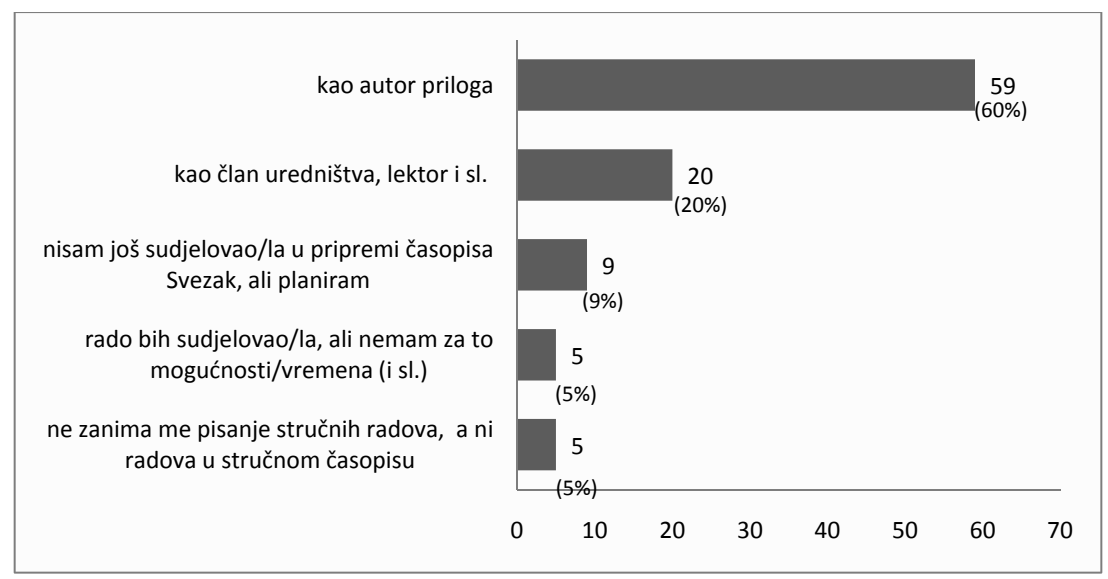

Slika 2. Sudjelovanje u pripremi časopisa Svezak

Zapažena aktivnost Društva je izdavanje popularno-stručnog časopisa Svezak. Odgovori sudjeluju li i na koji način ispitanici u pripremi časopisa Svezak nalaze se na slici 2. Ispitanici su imali mogućnost višestrukog odabira odgovora. Pokazalo se kako je 77\% ispitanika (njih 59) sudjelovalo u pripremi Sveska u svojstvu autora priloga, $26 \%$ ispitanika (njih 20) u radu uredništva, dok se $12 \%$ ispitanika (njih 9) planira uključiti u rad na pripremi Sveska, a 6\% ispitanika (njih 5) to bi voljelo, ali trenutno nemaju mogućnosti zbog manjka vremena i sl. Samo 6\% ispitanika (njih 5) navelo je da ih ne zanima rad u časopisu Svezak.

\subsection{Područja interesa}

U ovoj skupini pitanja istražena su područja interesa ispitanika vezana uz programe i aktivnosti Društva i Hrvatskog knjižničarskog društva. Ispitanici su mogli označiti i/ili dopisati područje koje ih zanima neovisno o njihovu postojećem angažmanu u Društvu/Hrvatskom knjižničarskom društvu. Slijede odgovori prema učestalosti:

- časopis Svezak (kao autor priloga 73\% ili 56 ispitanika, rad u uredništvu $31 \%$ ili 24 ispitanika)

- druženje i razmjena stručnih iskustava s kolegama iz različitih mjesta i knjižnica (60\% ili 46 ispitanika)

- sudjelovanje na stručnim izletima (47\% ili 36 ispitanika)

- društvene mreže i administriranje internetskih stranica Društva (35\% ili 27 ispitanika)

- odnosi s javnošću (19\% ili 15 ispitanika) 
- sekcije i komisije Hrvatskog knjižničarskog društva (17\% ili 13 ispitanika)

- upravna tijela Društva (12\% ili 9 ispitanika).

Iz navedenih odgovora vidljivo je kako najviše ispitanika zanima rad na časopisu Svezak te druženje i razmjena stručnih iskustava.

\subsection{Ciljevi učlanjivanja i očekivanja od Društva}

Jedan od najvažnijih zadataka ankete bio je saznati ciljeve učlanjivanja i očekivanja ispitanika od regionalnog Društva. Slijede nabrojeni ciljevi učlanjivanja poredani prema učestalosti:

- upoznavanje rada drugih knjižnica (88\% ili 68 ispitanika)

- druženje s kolegama ( $83 \%$ ili 64 ispitanika)

- stručno usavršavanje (77\% ili 59 ispitanika)

- veće zadovoljstvo u radu (53\% ili 41 ispitanik)

- objavljivanje stručnih radova (51\% ili 39 ispitanika)

- putovanja (51\% ili 39 ispitanika)

- stručno napredovanje u zvanju (44\% ili 34 ispitanika)

- bolji uvjeti rada (31\% ili 24 ispitanika)

- stjecanje znanja i iskustva za pronalaženje boljeg posla (17\% ili 13 ispitanika).

Ispitanici su mogli na ovo pitanje odabrati više odgovora ili dopuniti postojeće odgovore. Prema rezultatima upitnika, glavni cilj Društva - okupljanje knjižničnih djelatnika iz svih vrsta knjižnica i poticanje njihova stručnog usavršavanja - podudara se sa stavovima ispitanika jer je iz odgovora na to pitanje vidljivo kako upravo to knjižničari od Društva i očekuju. Međutim dio ispitanika ima očekivanja koja Društvo ne može ispuniti, a to je osiguravanje boljih uvjeta rada.

\section{Rasprava i zaključak}

Pilot-istraživanje o potrebama i očekivanjima knjižničara od Društva prvo je istraživanje takve vrste u Društvu te je dalo važne uvodne spoznaje na temelju kojih će se kasnije moći dublje istraživati i analizirati. Pokazalo se kako ciljevi Društva i činjenica samog postojanja Društva nisu dovoljno poznati svim knjižničarima. S postojećom članarinom od 50 kuna većina je ispitanika zadovoljna i ne bi ju mijenjala. Informacije o radu regionalnog Društva knjižničari prate na različite načine, ali je najčešći izvor informacija časopis Svezak. Ima interesa za različite teme i područja u radu Društva, a glavni su razlozi neuključivanja ili 
nedovoljnog uključivanja u rad Društva manjak vremena, ali i manjak podrške u samim ustanovama - nemogućnost izostanka s posla i financijske nemogućnosti. Knjižničari su u anketi predložili bolju komunikaciju i suradnju među kolegama knjižničarima te veću transparentnost u radu Društva. Od Društva se očekuje da okuplja knjižničare, da održi svoju izdavačku djelatnost, organizira stručne skupove, promovira struku na različite načine, pruža potporu knjižničarima u radu te da nastavi inovirati rad i omogući povezivanje i razmjenu iskustava s drugim regionalnim društvima.

Bolja transparentnost riješit će se izdavanjem newslettera, osobnim razgovorom s ravnateljima ustanova pokušat će se ukazati na važnost dolaska knjižničara na skupštine, jer se one održavaju samo jedanput godišnje, a knjižničarima su možda jedini način da osobno komuniciraju s kolegama knjižničarima i na taj način dođu do novih stručnih informacija.

Knjižničarska se društva trebaju prilagoditi promjenama kako bi mogla nastaviti sa svojim društveno korisnim aktivnostima.

Ovo istraživanje može poslužiti kao pilot za opsežnije istraživanje interesa članova Društva te može bi biti primjer i ostalim regionalnim društvima knjižničara koja djeluju u sklopu Hrvatskog knjižničarskog društva kako bi i samo Hrvatsko knjižničarsko društvo dobilo uvid u interese svoga članstva te na taj način poboljšalo svoj rad.

\section{LITERATURA}

Društvo knjižničara Bilogore, Podravine i Kalničkog prigorja. Sastanak GO i Uredništva. 23. 11. 2016. [citirano: 2017-02-05] Dostupno na: http://www.drustvo-knjiznicara-bpkp.hr/sastanak-go-i-urednistva-23-11-2016/.

Društvo knjižničara Bilogore, Podravine i Kalničkog prigorja. Adresar članova Društva knjižničara Bilogore, Podravine i Kalničkog prigorja od 2008. do 2014., 5. veljače 2015.

Društvo knjižničara Bilogore, Podravine i Kalničkog prigorja. Adresar članova Društva knjižničara Bilogore, Podravine i Kalničkog prigorja od 2013. do 2015., 17. svibnja 2016.

Statut Društva knjižničara Bilogore, Podravine i Kalničkog prigorja, 25. rujna 2015. [citirano: 2017-02-05] Dostupno na: http://www.drustvo-knjiznicara-bpkp.hr/statut-drustva/.

Svezak : časopis Društva knjižničara Bilogore, Podravine i Kalničkog prigorja 18, 18(2016) Dostupno na http://www.drustvo-knjiznicara-bpkp.hr/svezak/svezak18/ Svezak_18_2016.pdf. 
Vrana, Radovan; Jasna Kovačević. Percepcija korisnika o knjižnici i knjižničnim uslugama kao temelj poslovne strategije knjižnice.// Vjesnik bibliotekara Hrvatske 56, 3(2013), 23-46 [citirano: 2017-02-05] Dostupno na http://www.hkdrustvo.hr/datoteke/1603/vbh/God.56(2013),br.3.

Zakon o udrugama. // Narodne novine 74 (2014-6-18)[citirano: 2017-02-05] Dostupno na http://narodne-novine.nn.hr/clanci/sluzbeni/2014_06_74_1390.html. 


\section{PRILOG 1. Upitnik}

\section{Upitnik Društva knjižničara Bilogore, Podravine i Kalničkog prigorja o potrebama i očekivanjima knjižničara (članova i nečlanova) od Druš- tva knjižničara BPKP}

Poštovani!

Društvo knjižničara Bilogore, Podravine i Kalničkog prigorja stručna je udruga građana, osnovana 1977. godine. Okuplja knjižničare iz svih vrsta knjižnica s područja tri županije: Koprivničko križevačke, Bjelovarskobilogorske i Virovitičkopodravske.

Društvo knjižničara BPKP u sastavu je matične udruge - Hrvatskog knjižničarskog društva, s kojim je udruženo još 15 regionalnih knjižničnih društava $s$ područja cijele Hrvatske. To znači da su svi članovi bilo kojeg regionalnog društva ujedno i članovi HKDa. Sjedište Društva knjižničara Bilogore, Podravine i Kalničkog prigorja u Bjelovaru je, u Narodnoj knjižnici "Petar Preradović". U sastavu Društva knjižničara BPKP danas je ukupno šezdeset šest narodnih, školskih i specijalnih knjižnica te 116 članova, od toga 111 redovnih i 5 počasnih članova. Prema Statutu, Društvom knjižničara BPKP upravlja Skupština te Glavni odbor i predsjednik Društva knjižničara BPKP izabrani na Skupštini Društva knjižničara BPKP.

Osnovni ciljevi rada Društva knjižničara BPKP usmjereni su promicanju knjižnica i knjižničarstva općenito. Društvo knjižničara BPKP nastoji ih ostvariti raznovrsnim aktivnostima - informiranjem i edukacijom, poticanjem međusobne stručne suradnje članova i razmjene iskustava dobre prakse između pojedinih knjižnica, kroz organizaciju stručnih skupova i putovanja, poticanjem i omogućavanjem stručnog usavršavanja članova itd.

Sve navedeno ostvaruje se i provodi angažmanom i u suradnji samih članova, pojedinaca uključenih u različite poslove i aktivnosti koji potpuno volonterski ulažu svoje sposobnosti i stručno znanje u rad Društva knjižničara BPKP na dobrobit svih njegovih članova i knjižničarstva kao struke u cjelini.

Društvo knjižničara BPKP financira se najvećim dijelom putem članarina samih članova, a dio te članarine, u skladu sa Statutom, uplaćuje se i HKDu radi sufinanciranja djelatnosti matične udruge. Rad Društva knjižničara BPKP također sufinanciraju narodne knjižnice na području koje Društvo knjižničara BPKP pokriva, uplaćivanjem određenog godišnjeg novčanog iznosa pomoći koji se razlikuje od knjižnice do knjižnice i razmjeran je veličini pojedine knjižnice. Pojedine aktivnosti Društva knjižničara BPKP sufinanciraju se sredstvima gradova i županija na čijem području Društvo knjižničara BPKP djeluje, preko javnih poziva za financiranje projekata u kulturi na koje se Društvo knjižničara prijavljuje, kao i 
kroz donacije i sponzorstva pravnih osoba, također preko natječaja na koje se šalju projekti. Troškovi izdavaštva (Svezak) dijelom se financiranju prodajom oglasnog prostora u tiskanim izdanjima.

S ciljem unapređenja rada Društva knjižničara i dodatnog približavanja njegovih aktivnosti interesima i potrebama članova te poticanja na učlanjivanje u Društvo knjižničara BPKP što više knjižničara s područja koje Društvo knjižničara BPKP pokriva, Glavni odbor odlučio je provesti anketno istraživanje namijenjeno i članovima i nečlanovima Društva knjižničara BPKP kojim želi ispitati stavove ispitanika prema Društvu te saznati koje su njihove potrebe i očekivanja od Društva knjižničara BPKP.

Molimo Vas da odvojite malo svog vremena i ispunite upitnik te tako doprinesete daljnjem razvoju Društva knjižničara Bilogore, Podravine i Kalničkog prigorja kako bi ono još više i uspješnije odgovaralo na potrebe svojih članova, kao i na potrebe svih knjižnica i knjižničara s ovog područja.

Hvala na suradnji!

Glavni odbor

Društva knjižničara Bilogore, Podravine i Kalničkog prigorja ožujak 2016.

*Obavezno 
Vjesnik bibliotekara Hrvatske 60, 1(2017), 221-242

\section{PODACI O ISPITANIKU}

1. 1.1. Spol *

Označite samo jedan oval.

$\mathrm{M}$

$\check{Z}$

2. 1. 2. Godina rođenja *

3. 1. 3. Radni staž u knjižničarstvu *

Označite samo jedan oval.

05 godina

510 godina

1020 godina

više od 20 godina

4. 1. 4. Stručna sprema / znanstveni stupanj: *

Označite samo jedan oval.

$\longrightarrow \mathrm{SSS}$

VŠS (bacc.)

VSS (mag.)

mr. sc.

dr. sc.

5. 1. 5. Zvanje u knjižničarstvu: *

Označite samo jedan oval.

pomoćni knjižničar

knjižničar 
diplomirani knjižničar

stručni suradnik knjižničar mentor

viši knjižničar

stručni suradnik knjižničar savjetnik

knjižničarski savjetnik

6. 1. 6. Radni status: *

Označite samo jedan oval.

zaposlen/a u narodnoj knjižnici

zaposlen/a u školskoj knjižnici

zaposlen/a u specijalnoj knjižnici (npr. muzejskoj, visokoškolskoj i sl.)

student/ica

umirovljenik/umirovljenica

nezaposlen/a osoba knjižničarske struke

Ostalo:

Prijeđite na pitanje broj 7.

\section{2. ČLANSTVO U DRUŠTVU KNJIŽNIČARA BPKP, ČLANARINA I} INFORMIRANJE O RADU DRUŠTVA KNJIŽNIČARA BPKP

7. 2.1. Članstvo u Društvu knjižničara Bilogore, Podravine i Kalničkog prigorja: * Označite samo jedan oval.

član sam Društva knjižničara BPKP

bio/bila sam član Društva knjižničara BPKP, ali više nisam

nisam nikada bio/bila član Društva knjižničara BPKP
Prijeđite na pitanje broj 9.

Prijeđite na pitanje broj 8.

Prijeđite na pitanje broj 8.

Prijeđite na pitanje broj 8. 


\section{2. ČLANSTVO U DRUŠTVU KNJIŽNIČARA BPKP, ČLANARINA I INFORMIRANJE O RADU DRUŠTVA KNJIŽNIČARA BPKP}

8. 2.2. Ako niste nikad bili član Društva knjižničara BPKP ili trenutno niste njegov član, molimo, označite razloge. *

Odaberite sve točne odgovore.

— nisam znao/la za postojanje Društva knjižničara BPKP i/ili nisam imao/la dovoljno informacija o mogućnosti učlanjenja

ne znam dovoljno o ciljevima i aktivnostima Društva knjižničara BPKP

aktivnosti Društva knjižničara BPKP ne odgovaraju / nisu odgovarale mojim potrebama i očekivanjima

moja ustanova ne podržava / nije podržavala aktivnosti rada u takvoj stručnoj udruzi iako moja ustanova načelno podržava rad Društva knjižničara BPKP, ne odobrava sudjelovanje u aktivnostima i programima Društva knjižničara BPKP koji se odvijaju za vrijeme radnog vremena

$\square$ članarina je previsoka

nemam dovoljno slobodnog vremena za angažiranje i rad u takvoj stručnoj udruzi

ne zanima me rad u stručnoj udruzi ovakvog tipa

Ostalo:

Prijeđite na pitanje broj 9.

\section{2. ČLANSTVO U DRUŠTVU KNJIŽNIČARA BPKP, ČLANARINA I INFORMIRANJE O RADU DRUŠTVA KNJIŽNIČARA BPKP}

9. 2.3. Godišnja članarina od 50,00 kn po mom je mišljenju: *

Označite samo jedan oval.

preniska, mogla bi biti i viša

previsoka, treba ju smanjiti

odgovarajuća 
10.2.4. Najviši iznos godišnje članarine koji biste bili spremni izdvojiti za članstvo u Društvu knjižničara BPKP je: *

Prijeđite na pitanje broj 11 .

\section{2. ČLANSTVO U DRUŠTVU KNJIŽNIČARA BPKP, ČLANARINA I INFORMIRANJE O RADU DRUŠTVA KNJIŽNIČARA BPKP}

11. 2.5. Obavijesti o radu i aktivnostima Društva knjižničara BPKP pratim na: *

Odaberite sve točne odgovore.

internetskoj stranici

FB-stranici

$\square$ u časopisu Svezak

ništa od toga

12. 2.6. Koliko često pratite obavijesti o radu i aktivnostima Društva knjižničara BPKP? * 1 rijetko - 5 često

Označite samo jedan oval.

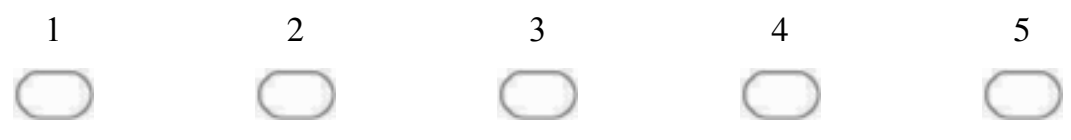

13. 2.7. Molimo, predložite dodatne oblike informiranja članova o radu Društva knjižničara BPKP!

Prijeđite na pitanje broj 14.

\section{AKTIVNOST I SUDJELOVANJE U RADU DRUŠTVA KNJIŽNIČARA} BPKP

14.3.1. Sudjelovanje na godišnjim skupštinama: * 
Označite samo jedan oval.

nikad Prijeđite na pitanje broj 15.

povremeno Prijeđite na pitanje broj 15.

često Prijeđite na pitanje broj 16.

redovito Prijeđite na pitanje broj 16.

\section{AKTIVNOST I SUDJELOVANJE U RADU DRUŠTVA}

15. U prethodnom pitanju označili ste kako NIKAD ne sudjelujete ili POVREMENO sudjelujete na godišnjim skupštinama. Molimo, navedite i obrazložite razloge. *

\section{AKTIVNOST I SUDJELOVANJE U RADU DRUŠTVA}

1. 3.2. Sudjelovanje u radu stručnih tijela/komisija/sekcija Društva knjižničara BPKP i Hrvatskoga knjižničarskog društva: *

Označite samo jedan oval.

da, sudjelovao/sudjelovala sam aktivno u radu Društva knjižničara BPKP, tj. u članstvu radnih tijela, odnosno komisija ili sekcija HKDa, ali mi je članstvo prestalo

Prijeđite na pitanje broj 17.

trenutno sam član radnih tijela, komisija ili sekcija Društva knjižničara BPKP/ HKDa i aktivno sudjelujem u njihovu radu Prijeđite na pitanje broj 18.

ne, nisam još sudjelovao/sudjelovala u radu tijela Društva knjižničara BPKP/ HKDa, ali bih se rado uključio/uključila u rad i planiram to Prijeđite na pitanje broj 19.

rado bih se uključio/uključila u rad Društva/HKDa, ali nemam za to mogućnosti Prijeđite na pitanje broj 20.

ne zanima me sudjelovanje u radu stručnih tijela Društva knjižničara BPKP/ HKDa Prijeđite na pitanje broj 21.

Prijeđite na pitanje broj 21. 


\section{AKTIVNOST I SUDJELOVANJE U RADU DRUŠTVA}

17. Napišite u kojim ste radnim tijelima, komisijama i sekcijama aktivno sudjelovali. *

Prijeđite na pitanje broj 21.

\section{AKTIVNOST I SUDJELOVANJE U RADU DRUŠTVA}

18. Napišite u kojim ste radnim tijelima, komisijama i sekcijama trenutno aktivni. *

\section{Prijeđite na pitanje broj 21.}

\section{AKTIVNOST I SUDJELOVANJE U RADU DRUŠTVA}

19. Napisali ste da niste još sudjelovali u radu tijela Društva knjižničara BPKP, ali biste se rado uključili u rad. Molimo, navedite područje interesa. *

Prijeđite na pitanje broj 21.

\section{AKTIVNOST I SUDJELOVANJE U RADU DRUŠTVA}

20. Što Vas sprečava da se uključite u rad Društva/HKDa? *

Prijeđite na pitanje broj 21.

\section{AKTIVNOST I SUDJELOVANJE U RADU DRUŠTVA}

21.3.3. Sudjelovanje na stručnim izletima u organizaciji Društva knjižničara BPKP (u zadnjih 10 godina): *

Označite samo jedan oval.

nikad

rijetko

ponekad

često

uvijek 


\subsubsection{Sudjelovanje u časopisu Svezak *}

Odaberite sve točne odgovore.

kao autor priloga

kao član uredništva, lektor i sl.

nisam još sudjelovao/sudjelovala u pripremi časopisa Svezak, ali planiram

rado bih sudjelovao/sudjelovala, ali nemam za to mogućnosti/vremena (i sl.)

ne zanima me pisanje stručnih radova ni rad u stručnom časopisu

\section{PODRUČJA INTERESA U RADU I AKTIVNOSTIMA DRUŠTVA KNJIŽNIČARA BPKP}

23. 4.1. Molimo, označite područja Vašeg interesa vezana uz program i aktivnosti Društva knjižničara BPKP. *

Odaberite sve točne odgovore.

aktivan rad u Glavnom i Nadzornom odboru

tematsko povjerenstvo

komisije ili sekcije HKDa

— autor priloga u časopisu Svezak

uredništvo časopisa Svezak

lektura/korektura časopisa Svezak

grafičko oblikovanje časopisa Svezak

marketing časopisa Svezak

projekti i programi (pisanje projekata, prijave na natječaje, provođenje)

— sudjelovanje u stručnim izletima

odnosi s javnošću (komuniciranje s medijima, press-konferencije, objave...)

administratorsko sudjelovanje - pisanje objava na internetskoj stranici 
W uredništvo internetske stranice

webdizajn ili webmaster

društvene mreže (administratorsko sudjelovanje)

druženje i razmjena stručnih iskustava s kolegama iz različitih mjesta i knjižnica

Ostalo:

24. Ukoliko ste označili da je vaše područje interesa tematsko povjerenstvo, molimo da napišete koje.

25. Ukoliko ste označili da je vaše područje interesa komisija ili sekcija HKDa, molimo da napišete koja.

\section{CILJEVI UČLANJIVANJA I OČEKIVANJA OD DRUŠTVA} KNJIŽNIČARA BPKP

26. 5.1. Molimo, označite svoja očekivanja od članstva u Društvu knjižničara BPKP.

Odaberite sve točne odgovore.

stalno stručno usavršavanje (npr. sudjelovanje na stručnim skupovima, edukativnim programima i sl., korištenje stručne literature koju izdaje Društvo knjižničara BPKP)

objavljivanje vlastitih radova iz knjižničarstva

upoznavanje i druženje s kolegama iz drugih knjižnica

upoznavanje rada drugih knjižnica te razmjena iskustava

putovanja, upoznavanja novih mjesta i krajeva

stručno napredovanje/stjecanje višeg zvanja

stjecanje znanja i iskustava potrebnih za pronalaženje boljeg posla 
Vjesnik bibliotekara Hrvatske 60, 1(2017), 221-242

postizanje boljih radnih uvjeta na sadašnjem radnom mjestu

veće zadovoljstvo u radu

veća plaća

Ostalo:

27.5.2. Molimo, navedite svoje prijedloge za unapređenje rada Društva knjižničara BPKP te vlastita očekivanja od Društva knjižničara BPKP: 